\title{
Prof. Geta(t)chew Haile
}

\section{(approx. 04/19/1931-June 10, 2021)}

Nafisa Valieva | ORCID: 0000-0001-8649-2963

ATER/allocataire postdoctorante, Collège de France: College de France,

Paris, France

nafisa-valieva@mail.ru

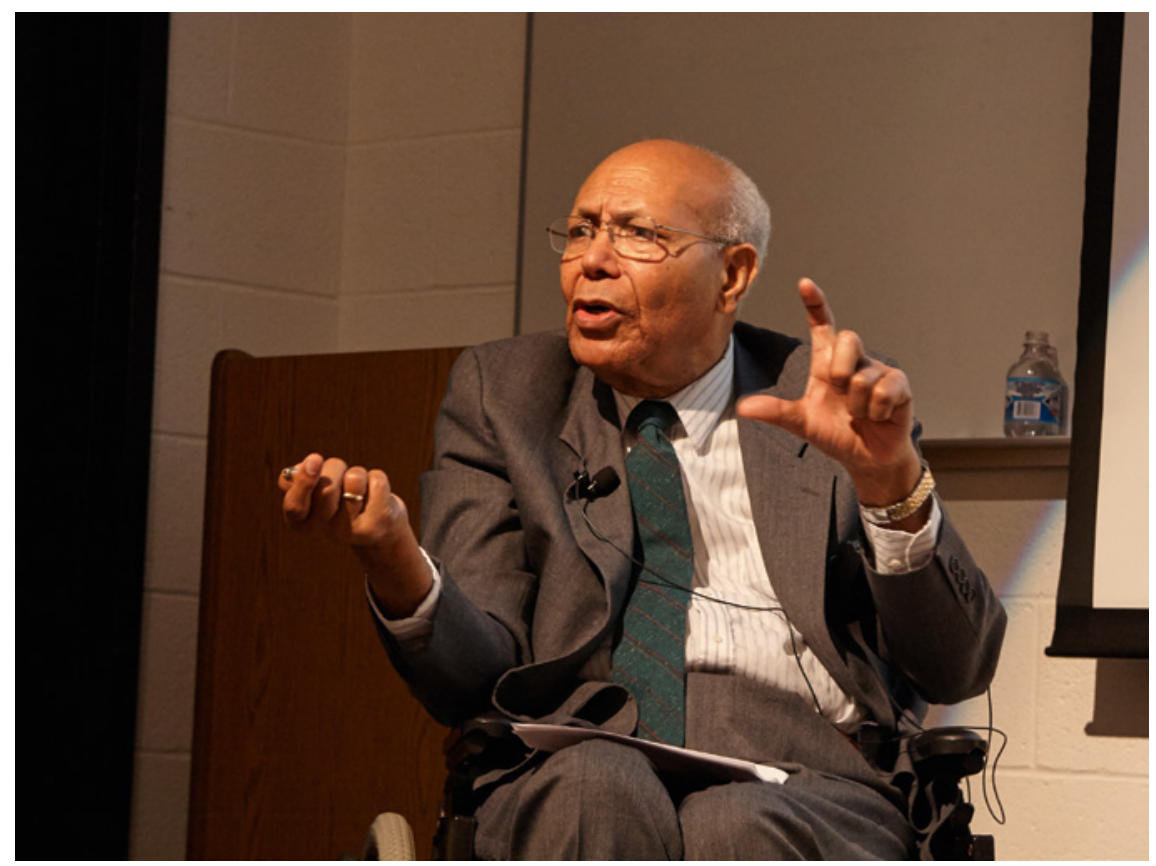

PHOTO BY WAYNE TORBORG

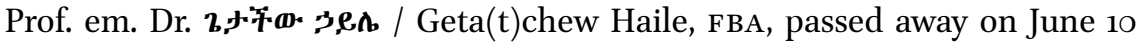
2021. Geta(t)chew (Amh. 'their lord') is his first name, Haile ('my force') - his father's name, a common way of naming children in Ethiopian Christian families. As Getatchew used to specify: 'Many people call me Mr. Haile, but I am Getatchew'. Getatchew's voice continues to sound through his children and grandchildren, through his students, colleagues, friends and people who met 
him, as well as directly through his texts in Amharic, English, German and audio/video recordings. Getatchew lived a long life, which he detailed in his autobiography, 'מ ute is an attempt to share with a reader an impression from Getatchew's life story 1 and his extraordinary personality.

No one knows when exactly Getatchew was born, approx. in June 1932, in a countryside of Ethiopia, Šawā Šankorā. Getatchew's father, Haile Woldeyes, was mariget $\bar{a}(\boldsymbol{m} \mathbf{6 1} ;)$ - the highest title within the Ethiopian Orthodox Church given to a person who reached a top of the ladder of traditional education who, as it is common in such 'academic families', started to teach Getatchew Geez while he was four.

In 1935 Italians troops invaded Ethiopia. Getatchew's birth village was bothered during the day time by Italian soldiers and by Ethiopian rebels ('ז个; during the night time, which made his family fly to Addis Ababā to Ințoțto Kidāna Məhrat church. Because of famine, Getatchew's mother took children and returned to Šankorā, from where Getatchew was sent to his uncle's place, where he spent a year as cattle's pastor. When Getatchew returned to Addis Ababā, he found his father teaching children at Holy Trinity church school. Being further prepared by his father, Getatchew entered the school and continued learning at school by his father's side also other subjects, such as English, geography, biology and math.

Already as a deacon, together with other three deacons and three priests, Getatchew had a chance to go to Cairo for further education. After two years of learning Arabic, from 1952-1957 Getatchew, together with his friend Amsalu Aklilu, was a student at Coptic Theological College in Cairo, where he got a Bachelor degree in Theology and at American University of Cairo, where he got a Bachelor degree in Sociology. While his stay in Cairo, Getatchew experienced how difficult is it to be a religious minority and got interested in how do Ethiopian Muslims live. (Later during the revolution Getatchew will write slogans in Arabic for his Muslim fellows.)

1 Main sources for writing this obituary were interviews with Professor Getatchew Haile, where he himself recollects different episodes of his life. These interviews are in Amharic and can be accessed via https://www.sbs.com.au/language/english/audio/life-and-legacy -prof-getachew-haile-pt-1; https://www.sbs.com.au/language/english/audio/life-and-legacy -prof-getachew-haile-pt-2;https://www.sbs.com.au/language/english/audio/life-and-legacy-prof -getachew-haile-pt-3; https://www.sbs.com.au/language/english/audio/life-and-legacy-prof-ge tachew-haile-pt-4; https://www.sbs.com.au/language/english/audio/life-and-legacy-prof-get achew-haile-pt-5. 
During his time in Egypt, while learning Arabic, Hebrew, Greek, Coptic and Latin, Getatchew, without being told, noticed that Arabic and Hebrew are in some way close to Geez and Amharic, while Greek, Coptic and Latin are not. Just as a hobby, Getatchew started his own comparative dictionary. When Murad Kamil, who was teaching Hebrew, saw accidently Getatchew's copybook, he said: 'Ah, you want to do Semitic Studies?' This is how Getatchew learnt about the existence of Semitic Studies in Germany and one of the greatest specialists of that time, Enno Littman.

From this moment Getatchew's plan was to become Littman's student. For this Getatchew started to learn German. An episode, narrated by Getatchew in one of the interviews, serves well as an illustration of his keen interest in learning languages, his simplicity and general curiosity:

Having learnt German alphabet, in order to learn how do the letter sound, Getatchew used to go to a deserted place in Cairo, where he would read German texts aloud. Once, being tired from reading, he sat down for a rest on his way back to school. While sitting, he saw an old blond man passing by. "This man must be German! What if I propose him a bit of money so that he teach me German?!', - thought Getatchew and approached an old man. The man agreed to help Getatchew, even though he turned out to be a Russian Count, who served as a horseman at the court of Empress Zawditu, one of those numerous Russians, who fled Russia after the revolution.

This count told Getatchew about a German church community, where Getatchew could practice German. Later on, pastor of this church helped Getatchew to find a scholarship for his education at Göttingen University. While studying at Göttingen, Getatchew planned his move from there to Tübingen University. Even when he learnt that Enno Littman passed away, Getatchew still wanted to move to Tübingen University, where he expected to find an established school of Semitic Studies. After a couple of months in Tübingen, Getatchew and Amsalu Aklilu made a journey around Europe while hitchhiking, which was full of adventures.

Having submitted his dissertation six months before the scholarship he had was over, Getatchew returned to Ethiopia. Seeking an employment as a teacher, he went to the ministry of education. As there was no vacant position at Haile Selassie I University (now AAU), upon recommendation of his friend, Dr Aklilu Habte, Getatchew went to the Ministry of Foreign Affairs, where he got employed during the rainy season. In September 1962 Getatchew received 
an offer to teach at the department of Ethiopian languages, which he gladly accepted and worked there until his exile. During these years Getatchew taught Geez, Geez literature, Amharic grammar and Arabic. There is a woman in Getatchew's shadow, his wife and assistant Məsrāq, who stood by Getatchew's side since 1964 .

Getatchew had the spirit of the revolutionaries. He was very excited when the 'dark Ethiopian political landscape was about to change', according to his autobiography, but when the forest was to be chopped he became a chip: he himself was shot and nearly died. Getatchew was rescued for a medical treatment in England and then in 1976 came to the USA as a refugee, where he spent the rest of his life in a wheelchair.

During his years in Ethiopia Getatchew was part of the microfilming project, initiated by Abuna Tewoflos, Patriarch of the Ethiopian Orthodox Church, and conducted by Ethiopian Manuscript and Microfilm Library and Hill Museum and Manuscript Library and in the USA he landed in Collegeville, where he was cataloguing microfilmed Ethiopic texts. Getatchew saw his role in spreading knowledge about Geez and Amharic written sources, seeing it, besides, as a 'contribution of Ethiopia to the study of church history' (see eight catalogues of the Ethiopic texts!).

Being a paraplegic scholar in exile for more than forty years, Getatchew did not immerse into misery, but was a constant support for people around him and for the scholars around the world. People used to say that if you mention Getatchew to a taxi driver in Washington DC, he would drive you for free ...

Rest in peace. 